\title{
PELANGGARAN ASUSILA BAGI PERUMAH TANGGA DALAM KAJIAN AGAMA BUDDHA
}

\author{
Warsito \\ STABN Sriwijaya Tangerang Banten \\ warsitosuranata79@gmail.com
}

\begin{abstract}
ABSTRAK
Kejahatan kesusilaan sering terjadi dalam kehidupan masyarakat, pada kenyataannya kejahatan ini semakin lama semakin meningkat, untuk itu pelu penanganan yang serius dan kerjasama antara penegak hukum dengan masyarakat. Kejahatan kesusilaan ini bisa menimpa kehidupan anak-anak, remaja dan perumahtangga. Bentuk perilaku yang menyimpang adalah yang terjadi adalah tindakan perzinahan, pemerkosaaan dan pencabulan. Dalam kehidupan rumah tangga, perilaku yang menyimpang yang terjadi adalah tindak pidana perzinahan.

Jenis penelitiannya adalah penelitian deskriptif dengan pendekatan tinjauan pustaka. Sumber data yang dilakukan berasal dari sumber utama yakni kitab undang-undang hukum pidana dan buku-buku literatur Buddhis yang menunjang dalam penelitian ini. Penelitian ini untuk mengetahui secara sosiologis dan keagamaan mengenai pelanggaran asusila bagi perumahtangga dalam kajian agama Buddha.

Banyak perumahtangga yang belum mengetahui bagaimana cara mengatasi jika terjadi pelanggaran asusila di lingkungan keluarga serta apa yang seharusnya dilakukan dalam aspek yuridis, sosiologis dan keagamaan. Keberlangsungan hubungan dalam rumah tangga dipengaruhi permasalahan ekonomi dan kecocokan antar pasangan. Dua masalah utama ini menjadi hal yang sangat penting diperhatikan, karena merupakan masalah pokok yang menjadi permasalahan utama dalam keluarga. Kesadaran dalam mematuhi peraturan perlu ditingkatan sehingga masalah-masalah kesusilaan yang akan muncul dapat dicegah yang pada akhirnya jika tetap muncul akan mudah untuk diatasi.
\end{abstract}

\section{ABSTRACT}

The crime of decency often occurs in the life of the community, in fact the crime is increasingly increasing, for that need serious handling and cooperation between law enforcement with the community. This crime of morality can affect the lives of children, youth and householders. A distorted form of behavior is what happens is adultery, rape and obscenity. In domestic life, the perverted behavior that occurs is the crime of adultery.

The type of research is descriptive research with literature review approach. Sources of data carried out come from the main source of the criminal law code and books of Buddhist literature that support in this study. This study is to find out sociologically and religiously about immoral violations for householders in Buddhist studies. Many householders do not yet know how to deal with violations of immorality in the family environment and what should be done in juridical, sociological and religious aspects. The sustainability of domestic relationships is influenced by economic problems and compatibility between partners. These two main issues become very important to note, because it is the main problem that becomes the main problem in the family. Awareness in obeying the rules needs to be increased so that the emerging moral problems can be prevented which in the end if they remain will be easy to overcome. 


\section{Pendahuluan}

Tindak pidana kejahatan yang terjadi di masyarakat sangat beragam. Bentuk perilaku menyimpang yang sering terjadi adalah perzinahan, pemerkosaan dan pencabulan. Dari semua tindak kejahatan tersebut terjadi dikarenakan berbagai macam faktor yang mempengaruhinya, seperti keterpaksaan seseorang melakukan tindak kejahatan pencurian yang dikarenakan faktor ekonomi, faktor lingkungan atau terikut dengan lingkungan yang ada di sekitarnya dan sebagainya. Adapun yang merupakan penyebab terjadinya pencabulan adalah (1) adanya kemajuan teknologi yang menciptakan produk-produk baru dan canggih, contohnya membuat film-film dan video yang membawa pengaruh negatif (2) adanya buku bacaan, majalah yang berbau pornografi (3) masalah ekonomi yang membelit (4) rendahnya pemahaman akan nilai-nilai agama dan moral.

Perbuatan-perbuatan yang terjadi seperti pencabulan dapat terjadi di lingkungan keluarga, ini tidak luput dari tekanan ekonomi, misalnya kurang layaknya tempat tinggal yang memiliki anak laki-laki dan perempuan yang beranjak dewasa yang mengharuskan tidur dengan satu ruangan. Masalah tindakan pencabulan dalam keluarga bukan menjadi rahasia lagi, ini terbukti banyaknya pemberitaan media masa maupun elektronik yang memuat kasuskasus tindak pidana pencabulan. Pada awalnya kasus pencabulan sulit diungkap karena dianggap tabu untuk disebarluaskan dan kalau diceritakan akan membawa aib bagi keluarga. Hal ini merupakan suatu tantangan bagi penegak hukum dan lingkungan masyarakat, oleh Karena itu maka kejahatan sudah seharusnya mendapat sanksi hukuman yang setimpal dengan perbuatannya. Menjadi tanggung jawab bersama, baik keluarga untuk memberikan pendidikan yang layak, juga termasuk pemerintah dan orang itu sendiri dalam mengontrol dirinya untuk tidak melakukan tindak pidana atau kejahatan yang dapat merugikan masyarakat bangsa pembangunan bangsa dan Negara. Mengenai peraturan untuk tidak melakukan perbuatan kotor dan tidak senonoh dapat diartikan sebagai menghargai jasmani sendiri dan tidak menyalahgunakannya. Manusia dapat mengetahui perbuatan baik dan buruk maka hal ini yang menjadikan manusia berbeda dengan hewan, untuk manusia dituntut berperilaku sebagaimana layaknya manusia. Aturan keempat adalah bersikap jujur (tidak berbohong). Aturan ini yang paling sering dilanggar. Jika seseorang ketahuan suka berbohong maka tak ada lagi orang yang akan mempercayainya. Berbohong merupakan cara yang paling cepat untuk menghilangkan rasa hormat orang atas diri kita. Ia yang tidak pernah berdusta dan penuh kasih sayang akan dikasihi dan dihormati semua makhluk dan pada saat meninggal dunia semuanya akan kehilangan. Tidak diperbolehkan untuk meminum minuman 
keras atau narkotika kecuali untuk kebutuhan dunia kedokteran. Karena kegiatan minum minuman keras dan obat-obatan akan merusak jasmani dan pikirannya yang cenderung akan melakukan perbuatan jahat.

Kebahagiaan yang diharapkan oleh perumahtangga adalah kebahagiaan lahir dan batin, kebahagiaan lahir dapat dicapai dengan terpenuhinya kebutuhan jasmani. Kebutuhan jasmani dapat terpenuhi bila para pasangan hidup rajin dan bersemangat dalam mengerjakan apa saja, ia tampil dan produktif, berminat dan meneliti cara-cara yang ditempuh, serta mampu mengelola secara teratur, menjaga dengan hati-hati kekayaan apapun yang telah diperolehnya, dan tidak membiarkannya hilang dan mudah dicuri. Memiliki teman-teman yang baik, tidak bergaul dengan orang jahat, menempuh cara hidup yang sesuai dan seimbang dengan penghasilannya.

Pelaksanaan sila bagi perumah tangga sangat perlu untuk dilaksanakan dalam kehidupan sehari-hari, sehingga perilaku menyimpang seperti perbuatan asusila akan mudah dihindari. Dengan pelaksanakan sila yang baik, badan jasmaninya tanpa ternodai dengan kejahatan yang nantinya akan membawa ketenangan batin. Kejahatan kesusilaan banyak terjadi dalam kehidupan masyarakat, dalam perkembangannya kejahatan kesusilaan semakin meningkat, seperti kasus perzinahan, pemerkosaan, kekerasan seksual, perdagangan wanita untuk dipekerjakan di tempat prostitusi serta kasus kesusilaan lainnya. Ini terlihat bahwa kejahatan yang terjadi semakin berkembang dan mengalami peningkatan.

Jika melihat sejarah manusia, kejahatan sudah ada sejak dahulu kala, oleh karena itu kejahatan dapat dikategorikan sebagai perilaku menyimpang yang terjadi di masyarakat. Kejahatan terjadi di dalam kehidupan masyarakat dilatarbelakangi dengan perilaku dan pola pikir antar warga masyarakat yang berlawanan jenis kelamin. Kasus perzinahan adalah kejahatan yang sulit untuk dibuktikan, hanya jika kejadian itu diketahui oleh pasangan yang berbuat zina dan akan lebih sulit dikenali karena perbuatan itu dilakukan di tempat-tempat tertentu. Kasus perzinahan merupakan delik aduan, oleh karena itu menjadi kendala karena ada anggapan dari kalangan masyarakat yang merasa malu untuk melapor atau dapat dikatakan membuka aib keluarga sendiri.

Penegakan hukum dapat diartikan sebagai upaya untuk membuat hukum dapat berfungsi, beroperasi dan terwujud secara konkret, berdasarkan hal ini istilah penegakan hukum dengan istilah fungsionalisasi hukum dan konkretisasi hukum. Upaya hukum itu menjadi berfungsi, bekerja secara konkret diperlukan suatu proses, jadi penegakan hukum 
adalah suatu proses kerja dan berfungsinya hukum oleh aparat hukum terhadap perilakuperilaku yang secara formil materiil berlawanan dengan norma-norma hukum.

Dalam proses penegakan hukum terhadap perzinahan tidak hanya berpegang kepada ketentuan-ketentuan hukum pidana dan Kitab Undang-Undang Hukum Pidana (KUHP) tetapi harus dihubungkan dengan lingkungan sosial masyarakat. Dalam Kamus Besar bahasa Indonesia dijelaskan bahwa kata "susila" mengandung arti 1) baik budi bahasanya, beradab, sopan, tertib, 2) adat istiadat yang baik, sopan santun, kesopanan, keadaan, 3) pengetahuan tentang adab (Kamus Besar bahasa Indonesia, 2007 : 1110)

\section{Metode Penelitian}

Penelitian ini menggunakan pendekatan sosiologis dan keagamaan yang berbasis metode deskriptif dan kajian pustaka. Pendekatan kualitatif adalah tradisi tertentu dalam ilmu pengetahuan sosial yang secara fundamental bergantung dari pengamatan pada manusia. Metode deskriptif yaitu penelitian yang memberikan gambaran atau uraian atas suatu keadaan sejelas mungkin tanpa ada perlakuan terhadap objek yang diteliti (Ronny Kountur, 2005: 105). Metode deskriptif pada hakikatnya adalah mencari teori, bukan menguji teori dan menitikberatkan pada observasi dan suasana alamiah (Iqbal Hasan, 2005: 22). Riset pustaka adalah penelusuran pustaka lebih daripada sekedar melayani fungsi-fungsi studi pustaka, riset pustaka sekaligus memanfaatkan sumber perpustakaan untuk memperoleh data penelitiannya (Mestika Zed, 2008:1-2). Dalam penelitian ini dilakukan pengumpulan data pustaka yang membahas kajian yuridis dan sosiologis tentang pelanggaran asusila (kamesumichacara) bagi perumahtangga dan efek yang ditimbulkan dalam kelangsungan hidup berkeluarga, kemudian membaca, mencatat, dan mengolah bahan tersebut sesuai dengan pengalaman dan pengetahuan peneliti.

\section{Pembahasan}


Tindak pidana merupakan terjemahan dari istilah bahasa Belanda "strafbaar feit" selain itu dipakai juga istilah "delict" yang berasal dari bahasa latin "dellictum" dan dalam bahasa Indonesia dipakai istilah delik. Di samping istilah tindak pidana sebagai terjemahan "strafbaar feit" itu, dalam bahasa Indonesia juga terdapat istilah lain yang dapat ditemukan dalam beberapa hukum pidana dan beberapa perundang-undangan hukum pidana yaitu peristiwa pidana, perbuatan pidana, perbuatan yang boleh dihukum, perbuatan yang dapat dihukum dan pelanggaran pidana.

Unsur-unsur tindak pidana dikalangan ahli hukum belum ada kesatuan pendapat. Secara garis besar dibagi dalam beberapa golongan. Masing-masing golongan mempunyai pendapatnya sendiri. Unsur-unsur tindak pidana adalah :

1) Perbuatan manusia

2) Diancam dengan pidana

3) Melawan hukum

4) Dilakukan dengan kesalahan oleh orang yang bertanggungjawab

Unsur-unsur tindak pidana dibedakan menjadi 2 macam yakni unsur subyektif dan unsur obyektif. Unsur-unsur subyektif yaitu:

a) Orang yang mampu bertanggungjawab

b) Kesalahan artinya perbuatan harus dilakukan dengan kesalahan

Unsur obyektif yaitu :

a) Perbuatan orang

b) Akibat yang kelihatan dari perbuatan itu

c) Ada keadaan tertentu yang menyertai perbuatan itu

Tindak Pidana Perzinahan

Masalah yang terjadi pada manusia datang silih berganti, terkadang manusia sering kehilangan arah dan tujuan hidupnya. Karena masalah yang muncul diringi dengan nafsu yang berlebihan maka masalah tersebut semakin banyak dan beragam. Dalam diri manusia terdapat kemauan untuk hidup yang menjadi sumber bagi timbulnya kreativitas namun juga sering muncul kemauan untuk berkuasa yang akhirnya akan menjadi sumber berbagai tindakan buruk pada diri manusia. Masalah yang muncul dalam rumah tangga adalah kejahatan kesusilaan yakni perzinahan, perzinahan merupakan perbuatan yang tercela, melecehkan dan menodai perkawinan. 
Dalam delik perzinahan merupakan delik hukum yang disengaja, di luar perkawinan yang sah dan bertentangan dengan agama. Ini berarti unsur kesengajaan harus terbukti ada pada diri pelaku, agar dapat dinyatakan terbukti telah memenuhi unsur kesengajaan dalam dalam melakukan salah satu tindak pidana perzinahan dari tindak pidana perzinahan.

Pandangan hukum terhadap kasus kejahatan kesusilaan yang terjadi di dalam masyarakat dapat dilihat dengan beberapa kasus, seperti dalam kasus perzinahan, kasus ini dapat diproses apabila korban/orang yang dirugikan melaporkan pasangannya karena suatu perbuatan perzinahan seperti yang telah diatur dalam Pasal 284 KUHP, seperti kasus yang telah diketahui pasangan suami isteri menikah dan salah satunya melakukan perzinahan, akibat perbuatan pasangannya, korban dapat melaporkan kasus pasangannya ke polisi, maka pihak berwajib dapat melihat dari segi sahnya suatu perkawinan yang diatur dalam UndangUndang Nomor 1 Tahun 1974 tentang Perkawinan.

Unsur-unsur tindak pidana zina adalah sebagai berikut :

1. Pria dan Wanita.

Zina dilakukan secara bersama-sama, tidak dapat dilakukan oleh satu orang atau dua orang yang sejenis, artinya tidak dapat dilakukan pria dengan pria atau wanita dengan wanita.

2. Mengetahui lawan jenisnya terikat perkawinan.

Mengetahui merupakan unsur dolus (sengaja), jika tidak mengetahui maka bersangkutan tidak bisa dituntut.

3. Melakukan Persetubuhan.

Menurut hukum, dikatakan adanya persetubuhan apabila anggota kelamin pria telah masuk kedalam lubang anggota kelamin wanta sehingga mengeluarkan air mani.

4. Adanya Pengaduan.

Pengaduan tidak dapat dilakukan oleh orang lain selain suami/isteri dari yang berzina itu. Pengaduan dapat diartikan secara arti ketidaksetujuan. 


\section{Tindak Pidana Pemerkosaan}

Inti delik pidana di atas adalah dengan kekerasan atau ancaman kekerasan. Perbuatan tersebut dilakukan dengan paksa sehingga perempuan tersebut tidak dapat melawan dan terpaksa melakukan persetubuhan. Perempuan yang disetubuhi tersebut bukan istrinya, artinya tidak dikawini secara sah. Melakukan persetubuhan berarti terjadi hubungan biologis antara pembuat dan perempuan yang dipaksa tersebut.

Pemerkosaan cenderung merupakan aktivitas yang berulang, bukan merupakan perbuatan yang sekali sudah dan biasanya direncanakan. Berdasarkan penyebabnya perkosaan dapat dibedakan dalam beberapa tipe:

a. Tipe unjuk kekuasaan

Tujuannya adalah untuk menguasai korban lewat ancaman. Ancaman bisa diwujudkan dengan penggunaan senjata, kekuatan fisik tanpa menimbulkan cedera serius atau sekedar ancaman kosong.

b. Tipe meneguhkan kekuasaan

Bertujuan mengintimidasi dan menanklukkan korban. Motivasi dibaliknya adalah rasa lemah, tak berdaya, tak mampu atau tak memadai.

c. Tipe Marah, balas dendam

Tipe ini sangat berbahaya karena kadang-kadang sampai menimbulkan kematian pada korban. Dominannya dalam tindak perkosaan tipe ini adalah pelampiasan amarah, dendam dan kebencian, sedangkan unsure kepuasan seksualnya tidak terlalu penting. Tujuannya adalah untuk menyalurkan kebencian atau amarah terhadap kaum perempuan secara keseluruhan. Motifnya adalah membalas dendam terhadap suatu pengalaman buruk yang pernah diterima dari seorang perempuan pada masa lalu.

d. Tipe haus rangsangan

Pelaku mendapatkan kenikmatan, rangsangan seksual bukan dari unsure-unsur seksual dalam tindak perkosaanya, melainkan dari penderitaan yang dialami korbannya.

Tindak pidana pencabulan

Pencabulan merupakan kecenderungan untuk melakukan aktifitas seksual dengan orang yang tidak berdaya seperti kepada anak, baik pria maupun wanita, baik dengan kekerasan maupun tanpa kekerasan. Pengertian pencabulan atau cabul dalam kamus hukum dapat diartikan sebagai berikut: 
Pencabulan berasal dari kata cabul yang diartikan keji dan kotor, tidak senonoh karena melanggar kesopanan dan kesusilaan. Dalam pasal 289 KUHP dijelaskan bahwa: "Barang siapa dengan kekerasan atau ancaman kekerasan memaksa seseorang untuk melakukan atau membiarkan dilakukan perbuatan cabul, diancam karena melakukan perbuatan yang menyerang kehormatan kesusilaan dengan pidana penjara paling lama sembilan tahun”.

Pencabulan adalah kejahatan seksual yang dilakukan seorang pria atau wanita yang dilakukan dengan kekerasan atau tanpa kekerasan. Pencabulan mempunyai pengertian sebagai gangguan psikoseksual dimana orang dewasa memperoleh kepuasan seksual bersama seorang anak atau remaja. Ciri utamanya adalah berbuat atau berfantasi tentang kegiatan seksual dengan cara yang paling sesuai untuk memperoleh kepuasan seksual. Pengertian perbuatan cabul secara umum adalah perbuatan yang dinilai melanggar norma-norma kesusilaan, kesopanan dalam lingkungan masyarakat, semuanya itu dalam ruang lingkup nafsu birahi kelamin seseorang.

Jika melihat bentuk pencabulan maka cukup beragam, ada beberapa istilah tentang pencabulan adalah :

1. Exhibitionism seksual : sengaja memamerkan alat kelamin pada anak

2. Voyeurism : Orang dewasa mencium anak dengan bernafsu

3. Fonding : Mengelus, meraba alat kelamin anak

4. Fellatio : orang dewasa memaksa anak untuk melakukan kontak mulut.

Unsur tindak pidana pencabulan adalah :

1. Dengan kekerasan atau ancaman kekerasan

Dengan kekerasan adalah dimaksudkan setiap perbuatan yang dilakukan dengan kekuatan badan dengan kata lain dapat melemahkan orang. Ancaman kekerasan ditujukan terhadap wanita itu sendiri dan bersifat sedemikian rupa sehingga berbuat lain tidak memungkinan baginya selain membiarkan dirinya untuk disetubuhi.

2. Memaksa

(Memaksa berarti diluar kehendak dari wanita tersebut atau bertentangan dengan kehendak wanita tersebut. Pengertian memaksa ditafsirkan sebagai perbuatan yang menimbulkan rasa takut pada orang lain)

3. Melakukan atau membiarkan dilakukan perbuatan cabul

Suatu perbuatan yang dilakukan terhadap orang lain, akibat dorongan seksual yang ada pada diri untuk melakukan perbuatan cabul yang akan memuaskan nafsu birahinya). 
A. Faktor-faktor terjadinya tindak pidana kesusilaan

Faktor-faktor terjadinya tindak pidana dapat dilihat dari beberapa faktor :

1. Faktor rendahnya pendidikan dan ekonomi

Rendahnya tingkat pendidikan formal dalam diri seseorang dapat menimbulkan dampak terhadap masyarakat dan yang bersangkutan mudah terpengaruh melakukan suatu kejahatan tanpa memikirkan akibat dari perbuatannya. Karena pendidikan yang rendah maka berhubungan dengan factor ekonomi, dimana ekonomi yang lemah merupakan penyebab seseorang melakukan perbuatan yang melanggar norma hukum.

2. Faktor Lingkungan

Kejahatan asusila adalah tindak manusia terhadap manusia lainnya di masyarakat, maka kejahatan asusila tidak dapat dipisahkan dari masyarakat setempat. Lingkungan sosial banyak berpengaruh dalam membentuk tingkah laku kriminal sebab pengaruh sosialisasi seseorang tidak akan lepas dari pengaruh lingkungan.

Selain faktor di atas, peranan korban atau sikap korban sangat menentukan seseorang untuk melakukan kejahatan terhadapnya termasuk kejahatan asusila seperti korban kerapkali merangsang seseorang untuk melakukan kejahatan dan membuat orang menjadi penjahat.

\section{A. Pelanggaran asusila ditinjau secara sosiologis}

Di dalam sosiologi dikenal konsepsi organisasi sosial (social organization) yang mencakup pola-pola hubungan antar individu dan kelompok-kelompok yang timbul dalam proses interaksi sosial. Organisasi sosial sering menunjukkan betapa eratnya hubungan antara unsur-unsurnya yang terjadi kepincangan dan mengakibatkan goyahnya seluruh organisasi sosial. Organisasi sosial cenderung menekankan pada cita-cita adanya keserasian walaupun dalam kenyataan mungkin ada kurangnya harmoni dan konflik. Apabila masyarakat dalam jangka waktu tertentu mempunyai karakteristik atau ciri-ciri yang khas maka gejala tersebut diidentifikasikan sebagai suatu tertib sosial. Dalam menganalisis secara sosiologis terhadap masyarakat dipergunakan pola-pola organisasi sosial atau sistem sosial tertentu. Pola-pola tersebut dibedakan ke dalam tiga kategori atas dasar derajat tertentu yang mencakup kategori hubungan interpersonal, kelompok, dan tertib sosial.

Secara sosiologis kejahatan dibedakan dalam dua kategori dan dasar pembedaan tersebut didasarkan pada motivasi melakukan kejahatan tersebut. Dua kategori adalah terletak pada emosi dan rasio. Tingkah laku manusia dilandaskan pada kehendak atau kemauan tertentu. Kehendak atau kemauan yang relatif baik didasarkan pada keserasian 
antara emosi dengan rasio. Apabila salah satu faktor yang ditekankan maka sangat mungkin kemauan mempunyai warna yang negatif.

Kejahatan yang dilakukan atas dasar emosi atau dengan penanganan pada faktor emosional dinamakan tipe kejahatan ekspresif. Kejahatan ekpresif biasanya dilakukan karena ingin membalas dendam atau merasakan bahwa dirinya dihinggapi frustasi. Orang yang dihinggapi oleh tekanan mental yang sangat berat dan tidak mempunyai jalan atau cara mengatasinya dengan baik. Pelaku dari kehatan ekspresif tersebut adalah orang yang mempunyai hubungan erat dengan dunia kejahatan, sehingga ia diidentifikasikan sebagai penjahat profesional.

Tipe kejahatan lain yang didasarkan pada kejahatan atas dasar rasio dari pelakunya adakalanya mempunyai hubungan erat dengan dunia kejahatan atau kemungkinan ia melakukan kejahatan tidak begitu erat yang dapat disebut penjahat secara insidental. Ada kemungkinan pelaku terpengaruh baik oleh emosi maupun rasio secara bersamaan. Tidak mustahil bahwa segala kejahatan yang dilakukan didasarkan pada motivasi rasionalnya. Pelaku kejahatan akan mengalami halangan dalam hidupnya, dan untuk mengatasi emosi berperan lebih besar dari rasionya, yang semula menjadi dasar motivasi dari tindakannya.

Dalam aspek sosiologis dalam pelanggaran asusila adalah dikucilkan dalam kehidupan masyarakat. Untuk itu bagi perumah tangga hendaknya menghindari pelanggaran asusila maka akan berdampak positif dalam kelangsungan keluarga. Keluarga akan menjadi harmonis, tumbuh sikap saling percaya sehingga kehidupannya akan menjadi lebih baik.

Selain sanksi di atas terdapat sanksi yang bersifat preventif dan represif secara Sosiologis dan Keagamaan.

1. Tindakan preventif

a. Individu

Yang perlu dilakukan oleh setiap individu adalah berusaha untuk terus mencoba supaya tidak menjadi korban kejahatan asusila

b. Masyarakat

Pencegahan terhadap kejahatan asusila adalah usaha bersama yang harus dimulai sedini mungkin pada setiap anggota masyarakat. Upaya yang dilakukan agar mencegah terjadinya tindak pidana kesusilaan yaitu menciptakan suasana yang tidak menyimpang dengan tata nilai yang dianut oleh masyarakat. Usaha-usaha yang dilakukan mengadakan silaturahmi antara anggota masyarakat dilingkungan tempat 
tinggal dengan diisi ceramah-ceramah oleh tokoh masyarakat di lingkungan tempat tinggal.

c. Pemerintah

Usaha yang perlu dilakukan pemerintah adalah mengadakan penyuluhan hukum, karena pelaku asusila di masyarakat menunjukkan kesadaran hukumnya sangat rendah. Mengadakan penyuluhan keagamaan yang merupakan petunjuk bagi umat manusia untuk mendapatkan kesejahteraan lahir dan batin.

\section{Upaya represif}

Selain upaya preventif, upaya represif diperlukan sebagai bentuk penanggulangan kejahatan asusila di masyarakat. Penanggulangannya dilakukan oleh aparat hukum berupa penjatuhan atau pemberian sanksi pidana kepada perilaku kejahatan dalam hal ini dilakukan oleh kepolisian, kejaksaan, pengadilan dan lembaga pemasyarakatan.

3. Pelanggaran Asusila dalam Prespektif Ajaran Buddha

a. Pelanggaran Asusila

Susila dapat berarti aturan moralitas buddhis yang baik, namun bila mendapat awalan a maka artinya berubah menjadi aturan moralitas buddhis yang tidak baik. Kata asusila merupakan suatu tindakan yang tidak sesuai dengan norma yang berlaku. Dalam konteks asusila lebih ditekankan atau berkenaan dengan kesenangan nafsu indera nafsu indera kulit yang berhubungan dengan organ seksualitas. Tujuan aturan moralitas Buddhis adalah membina keharmonisan dan kepercayaan antara suami dengan isteri, serta mencegah perceraian dalam kehidupan rumah tangga. Dari sisi spiritual membantu meredamkan nafsu seksual yang meluap-luap, yang merupakan langkah awal menuju kearah pelepasan keduniawian.

Dalam moralitas Buddhis juga mengajarkan untuk menghindari perselingkuhan dan selalu mengendalikan nafsu seksual sehingga tidak terjadi kejahatan atau penyimpangan seksual yang dapat merugikan diri sendiri dan orang lain. Terdapat 4 (empat) faktor yang menyebabkan terjadinya pelanggaran aturan moralitas Buddhis yakni:

1. Terdapat orang yang tidak patut disetubuhi

2. Adanya niat untuk menyetubuhi orang tersebut

3. Melakukan usaha untuk menyetubuhinya

4. Berhasil menyetubuhi melalui usaha tersebut 
b. Pelanggaran asusila bagi perumahtangga

Dalam Aradhana Pancasila dijelaskan mengenai kamesumichacara yang secara harfiah artinya asusila. Suatu perbuatan dapat dikatakan sebagai perbuatan asusila apabila faktor yang mendasari hal tersebut terpenuhi :

1. Adanya objek

2. Mempunyai kehendak

3. Usaha, upaya untuk berbuat asusila

4. Berhasil melakukannya

Akibat jika melakukan perzinahan adalah :

1. Mempunyai banyak musuh, dibenci

2. Terlahir kembali sebagai waria

3. Mempunyai kelainan jiwa, senantiasa gelisah

4. Gagal bercinta atau sukar mendapat jodoh, dipisahkan dari orang yang dicintai

5. Tidak mendapatkan kebahagiaan berumahtangga

Setelah seseorang mengetahui faktor-faktor terjadinya pelanggaran moralitas serta dengan akibatnya, hendaknya dapat berupaya lebih baik lagi untuk menghindari pelanggaran sila. Dengan pelaksanaan moralitas ini sesungguhnya akan mendatangkan banyak hal-hal baik dapat muncul dalam kehidupan ini, bahkan dalam kehidupan mendatang akan memperoleh kebahagiaan surga.

Obyek yang menyebabkan pelanggaran aturan moralitas bagi seorang laki-laki adalah:

1. Wanita yang telah menikah

Meliputi semua wanita yang telah dan akan menjadi isteri orang lain tanpa memandang status atau latar belakang wanita tersebut, kecuali untuk wanita yang menjanda (bercerai dengan suaminya). Wanita yang telah menikah dan melakukan perselingkungan dengan pria yang belum menikah, berarti keduanya telah melakukan pelanggaran aturan moralitas Buddhis. Namun jika pria yang mengancam atau memaksa, maka pria tersebut yang bersalah.

2. Wanita yang masih dalam pengawasan keluarga/wali

Meliputi semua wanita di bawah umur yang belum menikah dan masih dalam perlindungan keluarga atau walinya tanpa memandang kedewasaan wanita tersebut. 
Kasus-kasus ini terjadi seperti kawin lari. Seorang wanita yang masih di bawah pengawasan orang tua melakukan perbuatan asusila dengan laki-laki yang bukan merupakan objek yang terlarang baginya, sehingga dapat dikatakan tidak melanggar aturan moralitas buddhis. Tetapi wanita tersebut dapat dikatakan melanggar Dhamma karena telah menodai dirinya sendiri dan menjatuhkan nama baik sendiri dan keluarga di dalam kehidupan masyarakat. Peraturan ini untuk menghindari adanya kawin lari atau kawin secara diam-diam yang bertentangan dengan keinginan dari pihak pelindung.

3. Wanita yang dilarang menurut adat istiadat, peraturan agama atau hukum Negara.

Wanita jenis ini adalah wanita yang masih dalam satu garis keturunan, artinya memiliki ikatan keluarga (kekerabatan) yang dekat. Pelanggaran terjadi apabila seorang ayah melakukan hubungan seksual dengan anak perempuannya (incest). Hubungan sedarah akan berpotensi tinggi menghasilkan keturunan yang secara biologis lemah baik fisik maupun mental.

Wanita yang dalam perlindungan Dharma adalah wanita yang menjalankan kehidupan suci yaitu upasaka atthasila, samaneri dan Bhiksuni. Seperti Wanita yang menjadi selir raja atau orang yang memiliki kekuasaan menjadi objek yang terlarang karena adanya hukum Negara atau daerah setempat.

Obyek yang menyebabkan pelanggaran aturan moralitas bagi seorang wanita adalah:

1. Bagi wanita yang sudah menikah, laki-laki selain suaminya sendiri adalah objek yang terlarang, namun duda (yang sudah bercerai) bebas untuk menikah kembali. Semua pria yang secara adat terlarang, seperti keluarga dekat dan menjalani kehidupan selibat, merupakan objek yang terlarang bagi wanita manapun. Buah karma yang bisa timbul jika melakukan perbuatan asusila adalah :

a) Tidak dihargai oleh orang lain

b) Mempunyai pasangan hidup yang tidak disenangi.

c. Upaya mengatasi tindak pidana asusila bagi perumahtangga

Pernikahan merupakan suatu ikatan suci yang dapat mempersatukan dua insan yang saling mencintai. Kehadiran orang ketiga sangat tidak diharapkan karena akan mengganggu keharmonisan hubungan rumah tangga. Perasaan curiga, cemburu dan akhirnya timbul kebencian dapat merusak kebahagiaan suami isteri yang seharusnya saling setia dan 
menyayangi, puas terhadap hubungan yang dijalani dan seharusnya tidak mengambil resiko perpecahan ikatan rumah tangga dengan pasangan lain.

Pencegahan hubungan seksual yang melukai orang lain adalah tujuan akhir yang harus diingat. Hubungan seks yang dipaksakan, yang timbul akibat kekerasan, seperti pemerkosaan merupakan pelanggaran berat tetapi beban moralnya hanya jatuh kepada si pelanggar bukan pada orang yang menjadi korban. Peraturan ini wajib dilaksanakan oleh orang telah mengambil delapan aturan moralitas (atthasila) atau sepuluh aturan moralitas (dasasila) yang telah menjalani hidup selibat. Keharusan untuk menghindarkan diri tidak hanya dari perilaku seks yang salah, tetapi juga semua hubungan seksual, setidaknya selama ikrar hidup suci.

Berat dan ringannya akibat melakukan pelanggaran aturan moralitas tidaklah persis sama, tergantung dari kekuatan niat yang mendorongnya, cara melaksanakannya dan tingkat kerohanian korban. Pemerkosaan akan mendapat hukuman yang lebih berat karena disertai dengan paksaan dan ancaman, contoh kasus seorang pemuda nanda memperkosa Bhiksuni Upalavana theri yang telah mencapai tingkat kesucian arahat, ia kemudian terlahir kembali di alam neraka Avici.

Dalam lima aturan moralitas Buddhis ketiga, tidak disebutkan objek binatang sebagai objek yang menyebabkan pelanggaran, sehingga kasus ini tidak dianggap sebagai pelanggaran aturan moral Buddhis ketiga. Walaupun begitu tidak disarankan dan tidak lazim di masyarakat karena pelakunya dapat dianggap melakukan penyiksaan terhadap binatang. Oleh karena itu dalam atthangika uposatha, kamesumicchacara veramani ditingkatkan menjadi abrahmacariya veramani yang artinya hampir sama namun terdapat penambahan objek berupa binatang. Aturan moralitas (sila) yang dilaksanakan dengan baik akan membuahkan akibat yang baik, dan sebaliknya. Hukum kamma akan memegang peranan yang sangat penting dalam pelaksanaan aturan moralitas Buddhis. 


\section{Daftar Pustaka}

Ali, Zainuddin. 2009. Sosiologi Hukum. Jakarta: Sinar Grafika

Arifin, Tajul. 2008. Metode Penelitian Hukum. Bandung: CV. Pustaka Setia.

Bodhi, Bhikkhu. 2006. Jalan Kebahagiaan Sejati, Karaniya. Jakarta.

Kamus Besar Bahasa Indonesia. 2007. Jakarta: Balai Pustaka

Pandita Abhayahema K.,Upasika. 1990. Vijja Dhamma, Tri Sattva Buddhist Centre

Paritta suci, 2005. Sangha Theravada Indonesia.

Satya Surya, Ronald . 2009. 5 Aturan Moralitas Buddhis pengertian, penjelasan dan penerapannya. Insight Vidyasena Production. Yogyakarta.

Sugiyono. 2008. Metode Penelitian Kuantitatif Kualitatif dan $R \&$ D. Bandung: Alfabeta Susanto, Agus. 2006. Sosiologi 1. Jakarta: Yudhistira

Tadisa Paramita Sthavira, Bhikkhu. tanpa tahun. Sebab Akibat Mengumbar Hawa Nafsu \& Seksualitas, Sangha Mahayana Buddhis Internasional

Virya, Jhana. 2009. Membina Keluarga Hita Sukhaya, CV. Yanwreko Wahana Karya

Widyadharma, MP. Sumedha. 2001. Dhamma-Sari, Yayasan Dana Pendidikan Buddhis Nalanda, Jakarta.

Wignjosoebroto, Soetandyo. 2008. Hukum dalam masyarakat perkembangan dan masalah. Bayumedia Publishing,Malang.

Wahid, Abdul. 2009. Perlindungan terhadap korban kekerasan seksual, Refika Aditama.

Zed, Mestika. 2008. Metode Penelitian Kepustakaan. Jakarta: Yayasan Obor Indonesia

2009.KUHPer, KUHP, KUHAP. Pustaka Yustisia. Yogyakarta. 